\title{
Experimental and Numerical Research on Seismic Performance of Earthquake-Damaged RC Frame Strengthened with CFRP Sheets
}

\author{
Lai Wang, ${ }^{1}$ Wei Xuan, ${ }^{1}$ Ying Zhang, ${ }^{2}$ Shuping Cong, ${ }^{1}$ Feng Liu, \\ Qiumei Gao, ${ }^{1}$ and Haitao Chen ${ }^{1}$ \\ ${ }^{1}$ Shandong Provincial Key Laboratory of Civil Engineering Disaster Prevention and Mitigation, \\ Shandong University of Science and Technology, Qingdao 266590, China \\ ${ }^{2}$ Institute of Structural Engineering and Disaster Reduction, Tongji University, Shanghai 200092, China \\ Correspondence should be addressed to Lai Wang; wlkdtjxy@sina.com
}

Received 19 April 2016; Accepted 3 July 2016

Academic Editor: Gianluca Cicala

Copyright (c) 2016 Lai Wang et al. This is an open access article distributed under the Creative Commons Attribution License, which permits unrestricted use, distribution, and reproduction in any medium, provided the original work is properly cited.

In order to assess the seismic performance of damaged reinforced concrete (RC) frame strengthened with carbon fiber reinforced polymers (CFRP) sheets, two experimental specimens with identical reinforcement ratio and geometric dimensions were designed following Chinese code for seismic design of buildings. Experimental specimens consist of a reference (undamaged) RC frame, namely, KJ-1, and an earthquake-damaged RC frame strengthened with CFRP sheets, namely, KJ-2. A pseudostatic test was conducted on the two specimens to simulate moderate earthquake damage. The strengthening effects of CFRP sheets on damaged RC frame were discussed in terms of hysteretic curve, skeleton curve, stiffness degradation, and ductility. In addition, numerical method based on fiber model method was utilized to analyze the seismic performance of KJ-1 and KJ-2 and it is compared with the experimental result. Both the results confirm that the method of exterior bonding CFRP sheets on the damaged RC frame has restored the seismic performance such as bearing capacity, stiffness, and ductility to its original undamaged level, and some of the seismic performance of the damaged RC frame strengthened with CFRP sheets is even better than the undamaged one, which proves that the method has significant effect in strengthening postearthquake-damaged RC frames.

\section{Introduction}

During Wenchuan Earthquake in $2008[1,2]$, reinforced concrete (RC) frame structures showed good seismic performance on the whole. Most of RC frame structures suffered minor damage such as some cracks on beam and column ends. However, many unequal-span buildings in primary and middle school were seriously damaged due to the low energy dissipation of this structure. Therefore, it is necessary to find a proper retrofitting approach to improve its seismic performance. Carbon fiber reinforced polymers (CFRP) with high strength, light weight, corrosion resistance, and wide adaptability are extensively used in structural rehabilitation as well as in new constructions [3, 4]. Many studies demonstrate that CFRP composite effectively improves the seismic performance of undamaged RC structure and components such as concrete (RC) columns [5, 6], beams [7], beam-column joints $[8,9]$, and frames [10].

Meanwhile many researches are concentrated on seismic behaviors of earthquake-damaged structures strengthened and/or repaired with CFRP sheets. Experiments on damaged RC beams [11-13] strengthened with CFRP sheets confirm that CFRP sheets significantly enhance the shear strength and ductility capacity, and the effect of different retrofitting scheme varies. A number of experiments [14-17] carried out on CFRP rehabilitation of RC columns verify that CFRP can increase ductility strength and energy dissipation. Beamcolumn joints of RC frame also played an important role in structural stability and seismic performance, since in many cases the whole structural failure starts with joint failure. The experiments [18-22] demonstrate that exterior bonded CFRP sheets on RC joints can upgrade shear strength, restore 


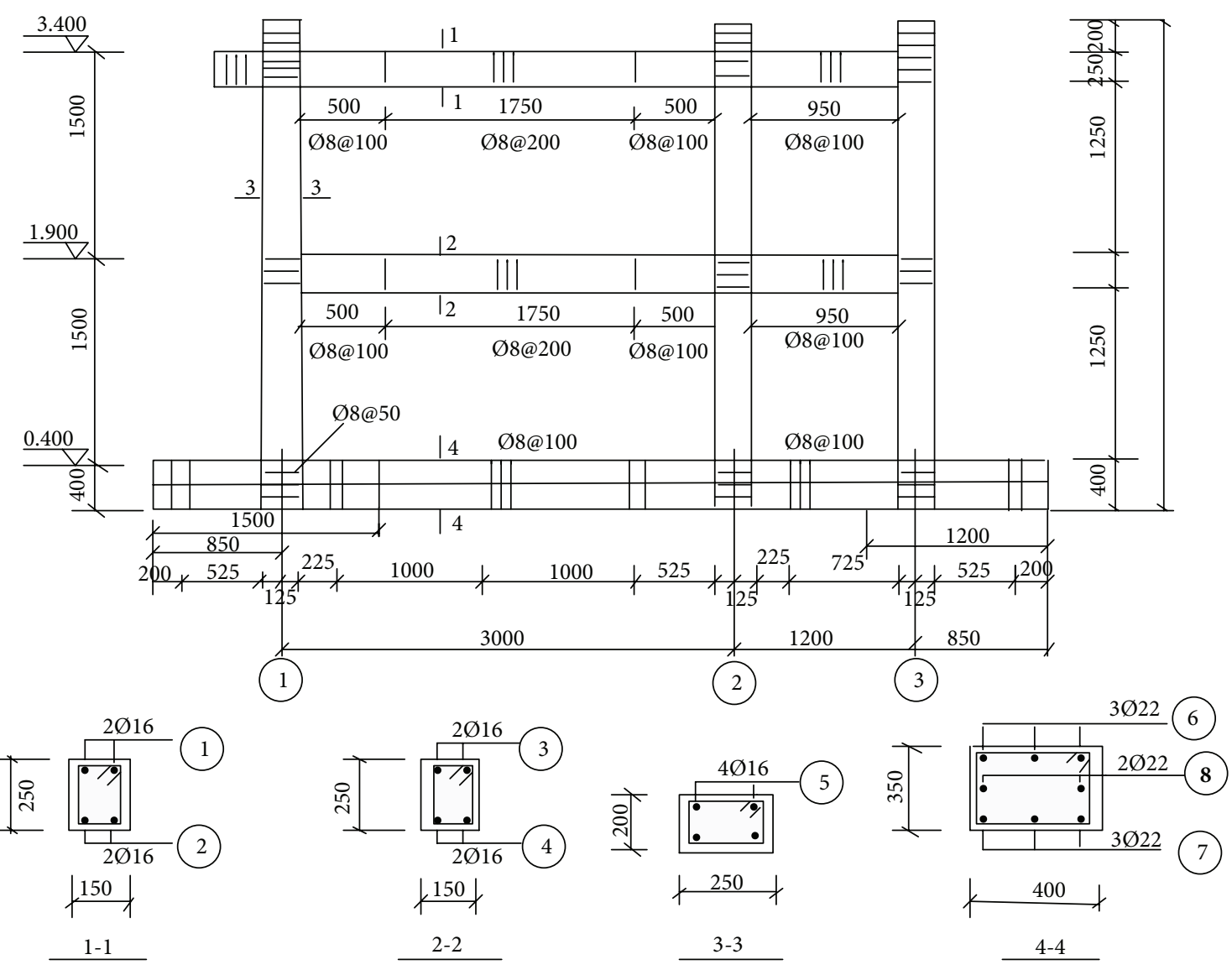

FIGURE 1: Dimension and reinforcement of specimen. $\varnothing$ represents the diameter of reinforcement; @ represents the interval of stirrups.

structural flexural stiffness, delay the degradation of stiffness, and bring the damaged joints back into normal service.

Effect of CFRP sheets has been assessed at the RC component level in terms of beams, columns, and joints. However, there are few researches conducted at the structural level. The strengthening and/or rehabilitating effect of exterior CFRP sheets at structural level is to be further studied. Wang et al. [23] examine CFRP sheets strengthened effect of a $1 / 3$ scale one-storey one-span RC frame adapting quasi-static approach to simulate severe earthquake. The experimental results indicate that CFRP sheets can remarkably enhance structural energy dissipation and improve the seismic performance of seriously damaged RC frame. Guo et al. [24] compare two earthquake-damaged RC frames strengthened by exterior bonded CFRP sheets and combination of both CFRP and steel sheets, respectively, with the original (undamaged) $\mathrm{RC}$ frame, while three $\mathrm{RC}$ frames have the same reinforcement ratio and geometric dimensions. Their experiment shows that the two strengthening procedures can increase the yield strength, ductility, ultimate displacement, and energy dissipation. They also illustrate that the procedure of exterior bonded CFRP sheets has better energy dissipation than that of combination of both CFRP and steel sheets.

The two aforementioned experiments are all carried out on one-storey one-span RC frame. The effect of strengthening with exterior bonded CFRP sheets on two-storey two-span
RC earthquake-damaged frame is assessed in this study adopting quasi-static procedure. Aimed at evaluating seismic performance including hysteretic behavior, ductility, ultimate load, ultimate displacement, and stiffness degradation, two RC specimens with similar geometric dimensions and reinforcement details are subjected to low-cyclic reversed loading. Then the experimental results are compared with numerical analysis based on fiber element method using OpenSees software. Both the results prove that the method of exterior bonding CFRP sheets can effectively improve the seismic performance of damaged RC frame.

\section{Experimental System}

2.1. Test Specimen. The two specimens, designed in accordance with the design core of China $[25,26]$, are two-storey and two-bay reinforced concrete frame structure with span lengths of $3.0 \mathrm{~m}$ and $1.2 \mathrm{~m}$, respectively. They are identical in dimension and reinforcement and the details are illustrated in Figure 1. The first specimen is used as reference specimen, namely, KJ-1. The other specimen, namely, KJ-2, is subjected to low-cyclic reversed loading so as to simulate moderate earthquake and then it is strengthened with exterior bonded CFRP sheets. The assessment of damaged RC frame is detailed in item 2 . 


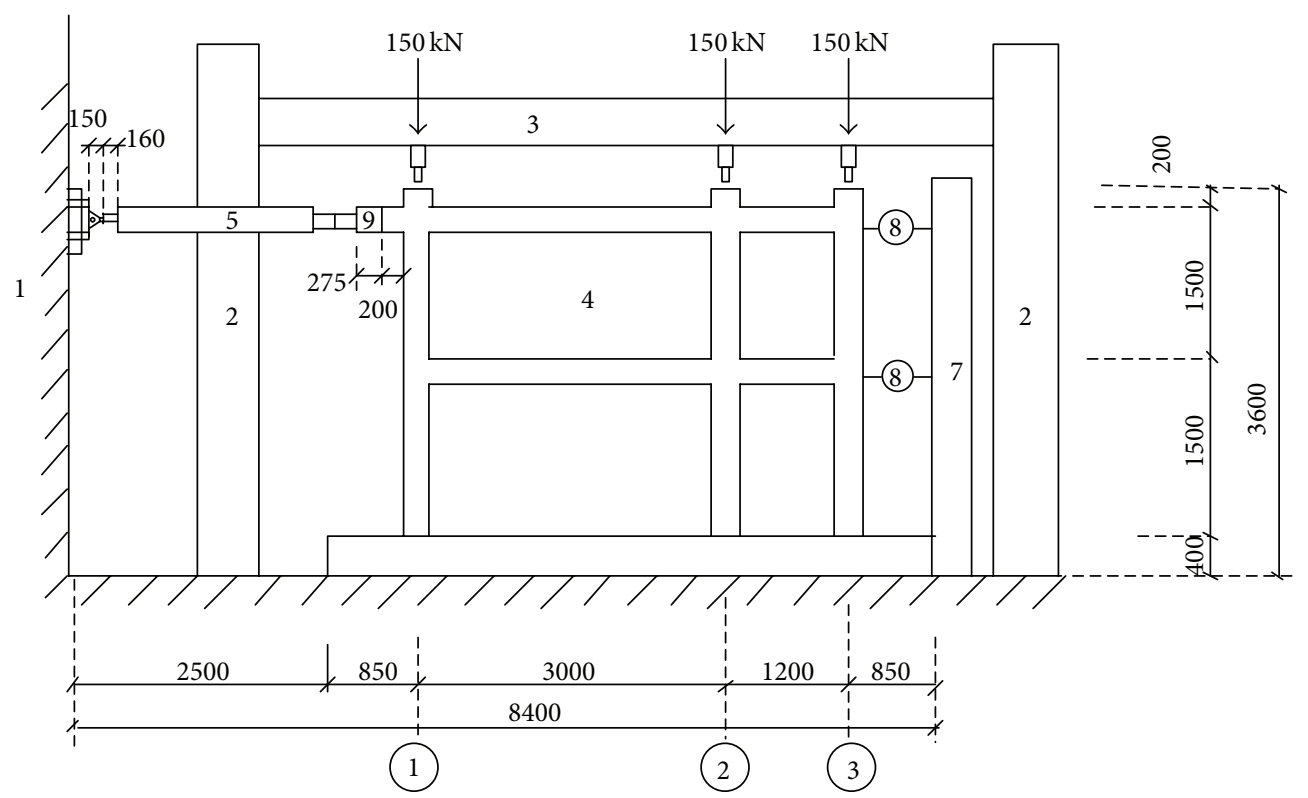

FIGURE 2: Test setup.

2.2. Material Properties. The concrete cubic compressive strength $f_{u}=23.8 \mathrm{~N} / \mathrm{mm}^{2}$ is determined from the test on three concrete cubes, which were cast at the same time and cured together with the two specimens, and the elastic modulus is calculated [26] as $E_{c}=2.73 \times 10^{4} \mathrm{~N} / \mathrm{mm}^{2}$. The yield strength and ultimate strength are obtained from actual test examples and are found to be $f_{y}=425 \mathrm{~N} / \mathrm{mm}^{2}$ and $f_{u}=565 \mathrm{~N} / \mathrm{mm}^{2}$ for longitudinal bars and $f_{y}=305 \mathrm{~N} / \mathrm{mm}^{2}$ and $f_{u}=445 \mathrm{~N} / \mathrm{mm}^{2}$ for transversal bars, respectively. The thickness, tension strength, and elastic modulus of CFRP sheets are as follows: sheet thickness, $t_{s}=0.111 \mathrm{~mm}$, tension strength, $f_{f}=3669 \mathrm{~N} / \mathrm{mm}^{2}$, and modulus, $E_{f}=2.42 \times$ $10^{5} \mathrm{~N} / \mathrm{mm}^{2}$.

2.3. Test Setup and Instrument. As illustrated in Figure 2, the quasi-static reversed cyclic lateral load is applied on the second storey beam end using a servohydraulic actuator, while constant vertical loads of $150 \mathrm{kN}$ are imposed on the top of three columns by hydraulic jacks which correspond to an approximate axial load ratio of 0.25 . The lateral loading uses dual controlled method of force and displacement [27]. Before yield of specimen, loading is under force control, repeating once for each level load with loading value of $20 \mathrm{kN}$; after yield, loading is controlled by lateral displacement value which is equivalently increased as integral multiples of yield displacement value of specimen, repeating two times for each level up to a load induced to $85 \%$ of ultimate bearing capacity. It is difficult to precisely define the yield load and displacement during the test. Normally, first inflection point reflected in force-displacement curve is considered as yield point, which is a little lower than the actual value [28-30]. In this experiment, as force and displacement are acquired dynamically, the first inflection point of $P-\Delta$ curve is identified as yield point; corresponding force and displacement are identified as yield force and displacement.

Displacements are monitored via displacement transducers at the locations shown in Figure 3. D1 and D2 displacement transducers are used to determine the lateral displacement at each storey level of RC frame during lateral reversed loading. D3 is used to monitor the integral slippage of the frame sparked by the lateral loading. D4-D16 located at the end of beams and columns are used to monitor the angular displacements. The strain of reinforcement and CFRP are measured using strain gauges and their positions can be seen in Figures 3 and 6, respectively.

\section{Evaluation of Damaged Frame and Strengthening Scheme with CFRP Sheets}

3.1. Safety Assessment of Damaged Frame. Low reversed cyclic loading test to simulate moderate earthquake damage is conducted on specimen KJ-2 under load control. During the test, when lateral load is $40 \mathrm{kN}$, the first crack appears; when load is $\pm 70 \mathrm{kN}$ (" + " representing the push direction and “-” representing pull direction) and the reinforcements (see Figure 3 ) at the bottom of C4 column and the end of B4 beam yield, the test is terminated. The average displacements are measured, respectively, as $17 \mathrm{~mm}$ in push and pull directions, and interstorey drift angle is $1 / 169$. This damaged specimen could be taken as moderate damaged RC frame in accordance with the suggested interstorey drift limit value of 1/150 [31, 32]. Hysteresis curve and cracks distributions are shown in Figures 4 and 5, respectively.

3.2. Strengthening Procedure. The strengthening scheme of damaged frame KJ-2 is as follows: CFRP sheets are bonded along the axial direction on the surface of tension region at 


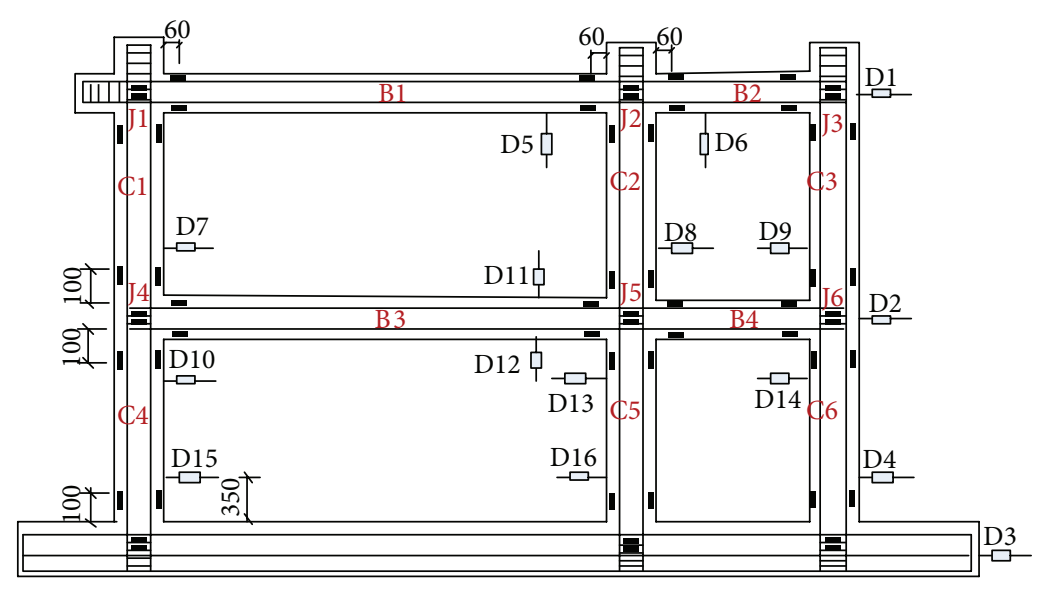

FIGURE 3: The number of frame components and arrangements of displacement transducers and strain gauges. C1-C4 represent columns; B1-B4 represent beams; J1-J6 represent joints.

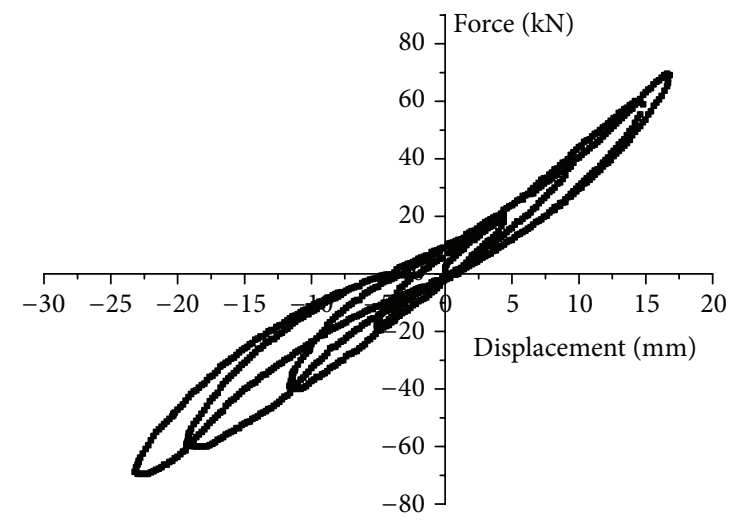

FIGURE 4: Hysteretic curve of KJ-2 unreinforced with CFRP.

the end of beams and columns and joint regions to enhance the structural tension capacity; annular CFRP sheets are wrapped perpendicular to the axial direction at the end of beams and columns; CFRP sheets are bonded in horizontal and vertical directions in the joint region and at the bottom of columns. The layout and details of CFRP sheets are shown in Figure 6. The photos of the damaged components strengthened by CFRP sheets are illustrated in Figure 7.

\section{Experimental Results and Numerical Analysis}

\subsection{Experimental Results and Discussion}

4.1.1. Reference Specimen KJ-1. During the test, the cracks appear at beam ends, column bottoms, and joint regions with the increase of lateral load. When load is $+40 \mathrm{kN}$, first flexural crack occurs at the left bottom of B4 (see Figure 3) beam and develops toward J5 joint; when load is $-40 \mathrm{kN}$, flexural crack generates at the right bottom of $\mathrm{L} 3$ beam and extends to J5 joint until diagonal cracks form. When load is $60 \mathrm{kN}$, the former cracks at 55 joint region grow and new titled cracks appear at $\mathrm{J} 2$ joint region; meanwhile, some flexural cracks can be observed at the left bottom end of L3 beam. When load is $-60 \mathrm{kN}$, cross-diagonal cracks occur at J2, J3, and J5 joints and several flexural cracks come out at the bottom of C4 column and left end of B3 beam. When load is $\pm 70 \mathrm{kN}$, the former cross-diagonal cracks at J2, J3, and J5 widen, while new cross-diagonal cracks appear at them and at J1 joint. Flexural cracks occur at the bottom of C5 and C6 columns. When load is $\pm 80 \mathrm{kN}$ and the reinforcements yield at B4 beam end, reinforced hinge is formed. The loading is under displacement control from then on. The average displacement in push and pull directions is $18.7 \mathrm{~mm}$, and $\Delta_{y}$ (nominal yield displacement) is set as $15 \mathrm{~mm}$. Plastic hinges occur successively at beam ends and column bottoms, cracks extend and widen gradually, and stiffness decreases noticeably along with the increase of loading. When displacement reaches $3 \Delta_{y}$ (i.e., 3 times to nominal yield displacement), lateral load is $142 \mathrm{kN}$ (i.e., the maximum bearing capacity of the specimen). When lateral load decreases to $120.7 \mathrm{kN}$ (i.e., $85 \%$ of maximum bearing capacity), the test is terminated. At component level, the failure mode of beams and columns is flexure failure, while it is shear failure at beam-column joints. The failure modes of beam ends, column bottoms, and joints are illustrated in Figure 8.

During the experiment, the plastic hinge occurs at beam ends of B4, B2, and B1 successively, and then the longitudinal reinforcements at column bottoms yield. The failure mode of the reference specimen is with beam and column plastic hinge collapse mechanism, conforming with the design philosophy "strong-column, weak-beam and strong-joint, weakmember" [25].

4.1.2. Specimen KJ-2 Strengthened with CFRP Sheets. After being strengthened with CFRP sheets, KJ-2 specimen is tested under load control. When lateral load is $80 \mathrm{kN}$, crack sounds come out of the strengthened region. When lateral load is $90 \mathrm{kN}$, the reinforcements at the bottom of C5 column yield and from then on the test is conducted under displacement control. The average displacement in push and pull directions is $14.1 \mathrm{~mm}$, while $\Delta_{y}$ is also set as $15 \mathrm{~mm}$. When the displacement increases to $4 \Delta_{y}$, tension failure of CFRP sheets at the 


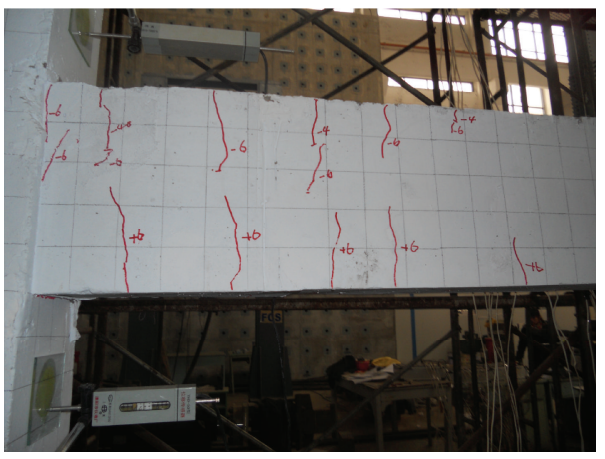

(a) Beam end

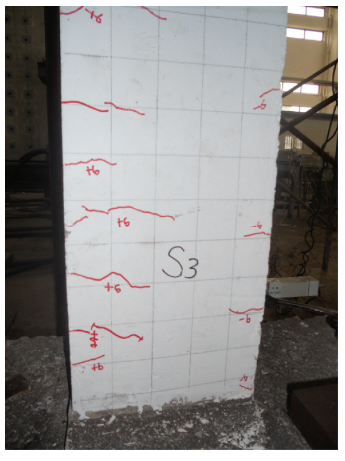

(b) Column bottom

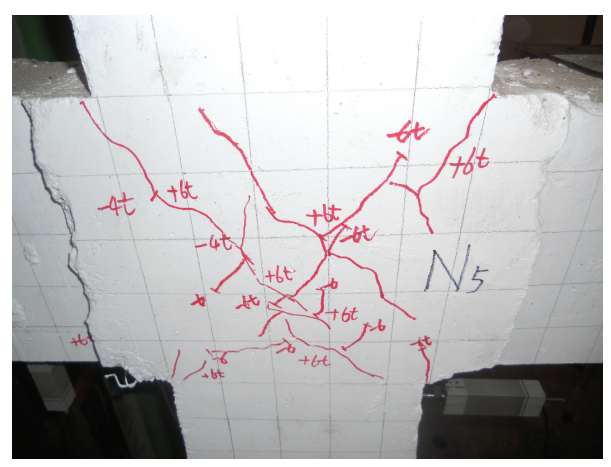

(c) Joint region

FIGURE 5: Cracks distribution of KJ-2 unreinforced with CFRP.

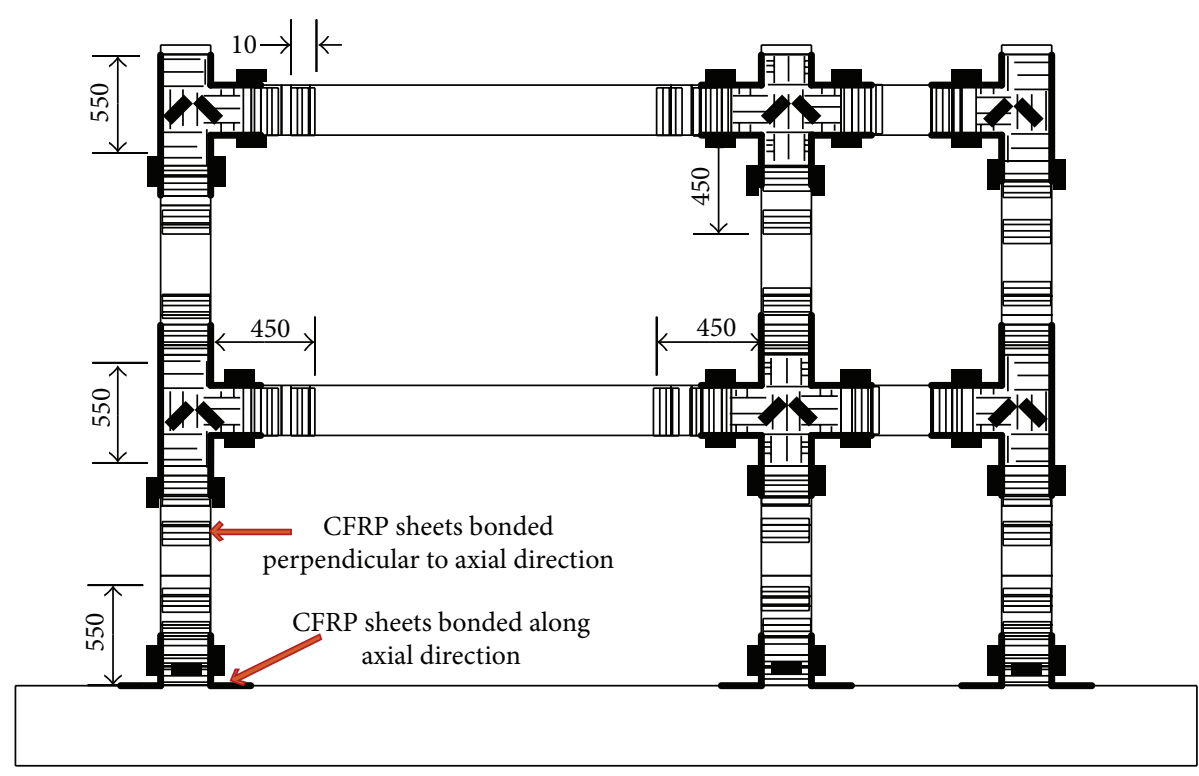

FIGURE 6: Arrangement of CFRP sheets and strain gauges.

bottom of $\mathrm{C} 4$ and $\mathrm{C} 5$ columns has been observed, while the other regions wielded by CFRP sheets are undamaged. At the point, the load is $169.8 \mathrm{kN}$ in push direction and $-134.2 \mathrm{kN}$ in pull direction, reaching the maximum bearing capacity of the specimen. When the displacement reaches $89.9 \mathrm{~mm}$ and $-71.4 \mathrm{~mm}$ in push and pull directions, and the corresponding load decreases to $144 \mathrm{kN}$ and $-124.6 \mathrm{kN}$, respectively (i.e., less than $85 \%$ of maximum bearing capacity), the experiment is terminated.

4.2. The Numerical Analysis. The numerical models of reference specimen KJ-1 and CFRP strengthened damaged specimen KJ-2 are established, respectively, using OpenSees software based on fiber element model adopting nonlinear beam-column element with 6 integrate points. The basic assumptions for this model include the following: (a) plane sections of concrete and CFRP would remain plane and normal to the neutral axis after bending, (b) buckling and slipping of CFRP sheets are neglected, (c) slippage between concrete and reinforcement is neglected, and (d) any adverse effect of cracks on the confinement of core concrete is neglected.

The column and beam elements of two specimens are defined, respectively, since they suffered different confined effect of stirrups and CFRP sheets. The two different fiber element models are shown in Figure 9. The material objects of steel and concrete are defined as follows.

4.2.1. The Relationship of Steel. Steel 02 material object considering isotropic strain hardening is employed in these numerical models. The yield strength and elastic modulus are determined by actual experiment. Parameters to control the transition from elastic to plastic branches named R0, CR1, and CR2 are 18, 0.925, and 0.15. The stress-strain curve of steel is shown as Figure 10(a).

4.2.2. The Relationship of Concrete. The concrete 02 material object in OpenSees software is employed in concrete numerical models. espco is concrete strain at the maximum stress 

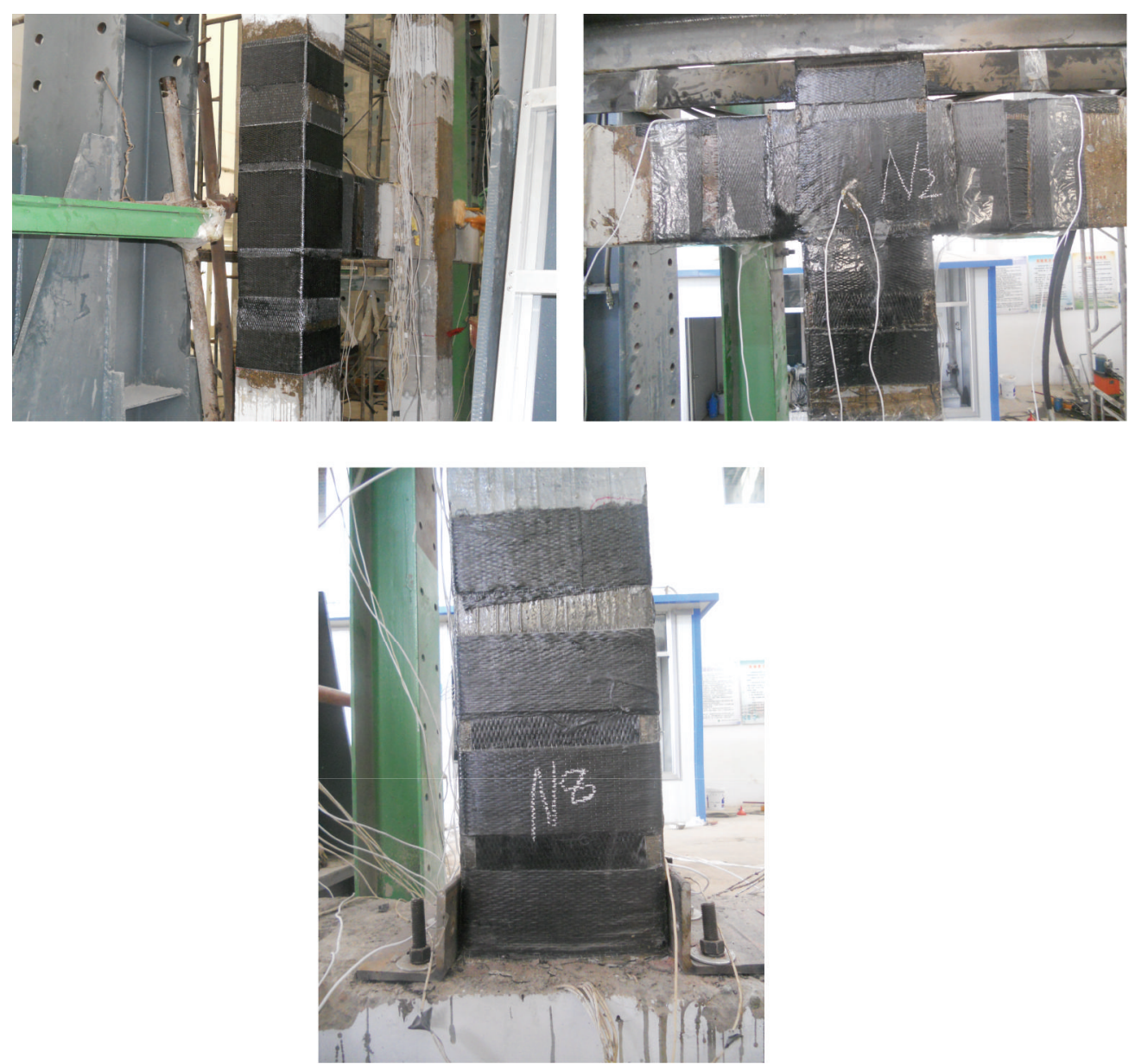

FIGURE 7: Details of CFRP sheets.

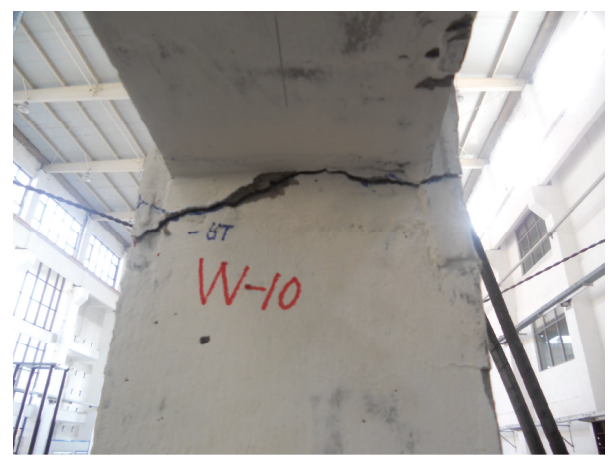

(a) Beam end

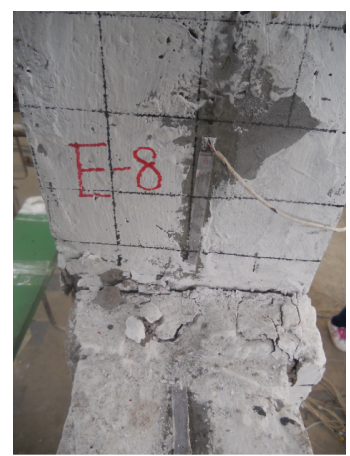

(b) Column bottom

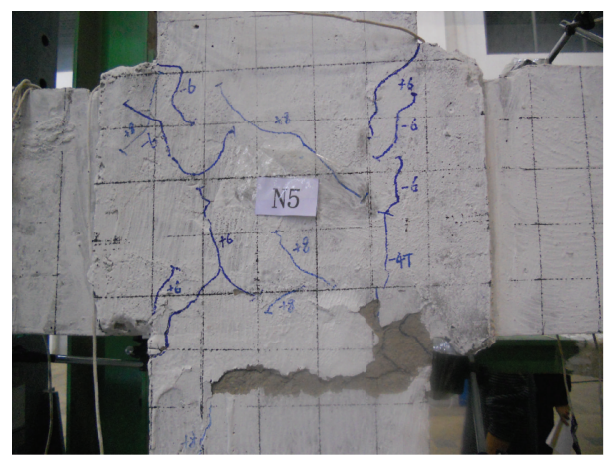

(c) Joint region

FIGURE 8: Specimen failure pattern.

point, $f_{p c}$ is concrete compressive cylinder strength, eps $U$ is concrete strain at the crushing strength, $f_{p c u}$ is concrete crushing strength, $\lambda$ is the ratio between unloading slope at crushing strain and initial slope, $f_{t}$ represents concrete tension strength, and $E_{\mathrm{ts}}$ is tension softening stiffness. And the initial elastic modulus $E_{c}=2.42 \times 10^{5} \mathrm{~N} / \mathrm{mm}^{2}$ is obtained from the test. The stress-strain curve of core concrete is illustrated in Figure 10(b): (a) Concrete 01 material object, which ignores the tensile strength of concrete, is used to simulate the covered concrete and core concrete at mid-span of $3.0 \mathrm{~m}$ beams since the stirrups confined effect on the latter is slight.

(b) Concrete 02 material object, which represents the core concrete confined with stirrups or CFRP sheets, adopting Scott-Park model [33] and Harajli model 


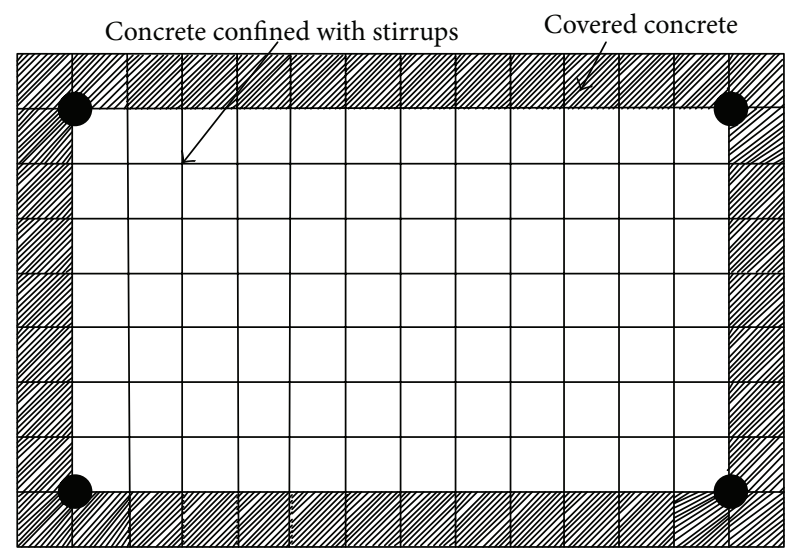

(a) Cross section confined with stirrups

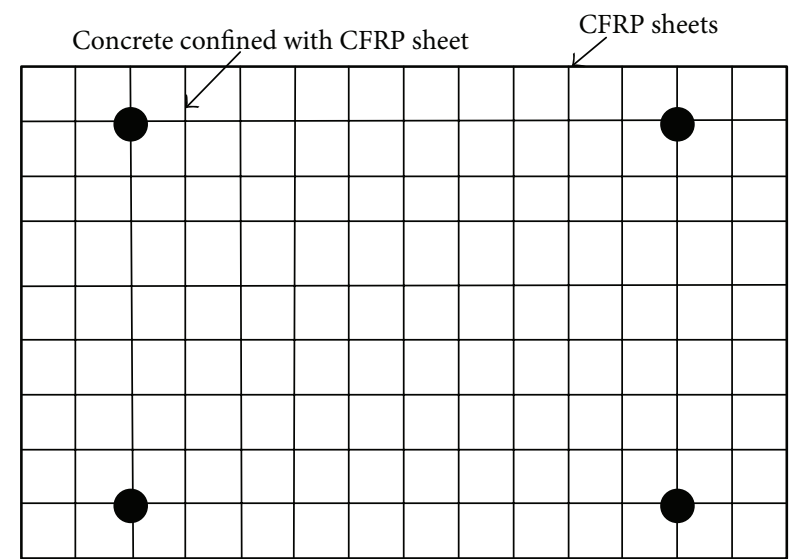

(b) Cross section confined with CFRP sheets

Figure 9: Sketch of fiber model.

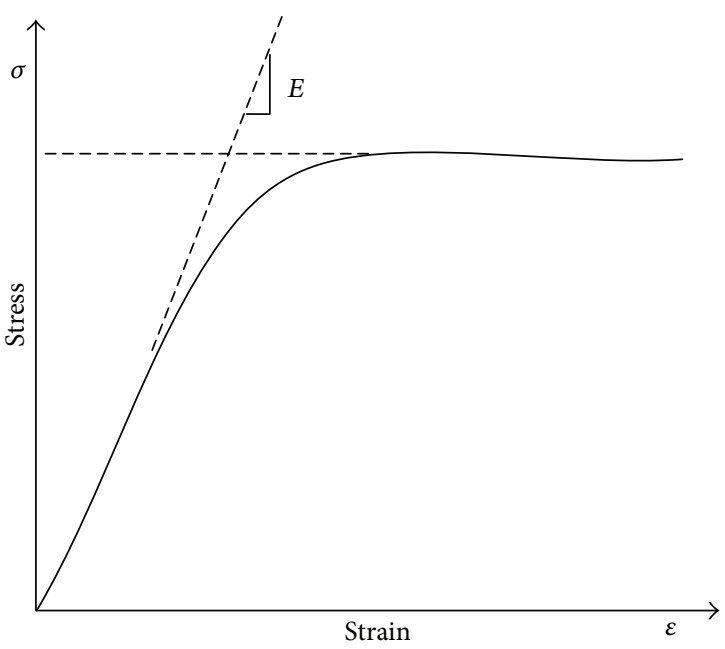

(a) Steel stress-strain curve

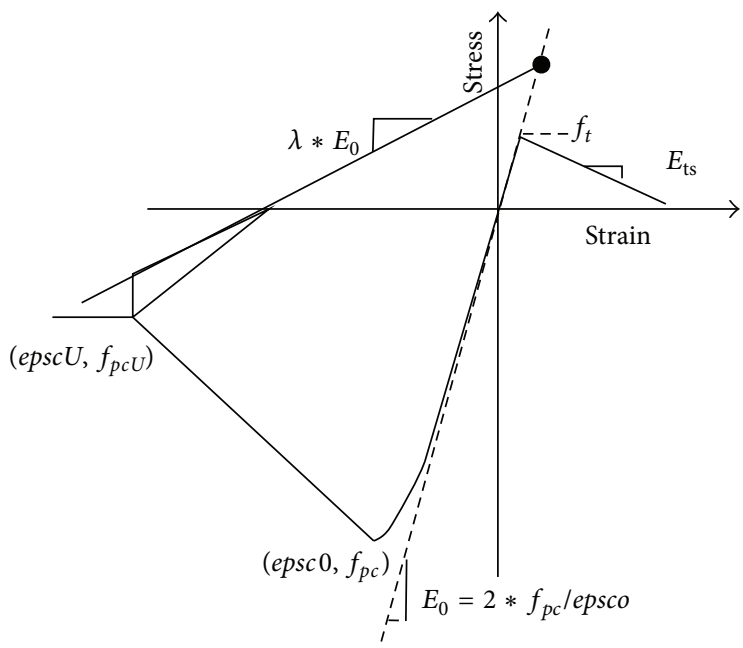

(b) Concrete 02 stress-strain curve

FIGURE 10: Stress-strain curve.

[34], respectively, is used to calculate stress and strain at peak and ultimate point.

\section{Analysis of Experiment and Simulation}

5.1. Hysteretic Behaviors and Skeleton Curves. (1) The hysteretic behaviors of specimens including reference specimen KJ-1 and strengthened specimen KJ-2 are illustrated as hysteretic curves in Figure 11. Their hysteretic loops are in reversed " $s$ " shape and present severe pinch phenomena at later stage of loading. The pinching on hysteretic loops of concrete structures varies in accordance with many factors, such as extension of concrete cracks, steel strain, relative slipping between steel and concrete, accumulation of concrete plastic deformation, and position of neutral axis.

Figure 11 demonstrates that the energy dissipation and ductility of KJ-2 are superior to KJ-1, for hysteretic loops of $\mathrm{KJ}-2$ are plumper compared to KJ-1. At initial stage of loading, the load and displacement relationship can be considered to be linear. With the increase of load and displacement, hysteretic loops become smoother and cover larger area, developing toward displacement axis. The values of load-bearing capacity and ultimate displacement of CFRP strengthened specimen (KJ-2) are higher than those of the reference one (KJ-1). This proves that the CFRP has dramatic strengthening effect. The effects of CFRP sheets include the following: (a) the confinement effect of CFRP improves strength of core concrete and delays the buckling of longitudinal reinforcement steel; and (b) wrapping CFRP sheets enhance the structural ductility and undertake part of bending moment which mitigates the relative slipping between steel and concrete.

In this test, the confinement effects of CFRP sheets are not utilized maximally because they are orthogonally bonded on surface of components in radial and hoop directions. The confinement effect of CFRP sheets would be greatly improved if the concrete cracks were dealt with in advance and CFRP sheets were validly anchored. 


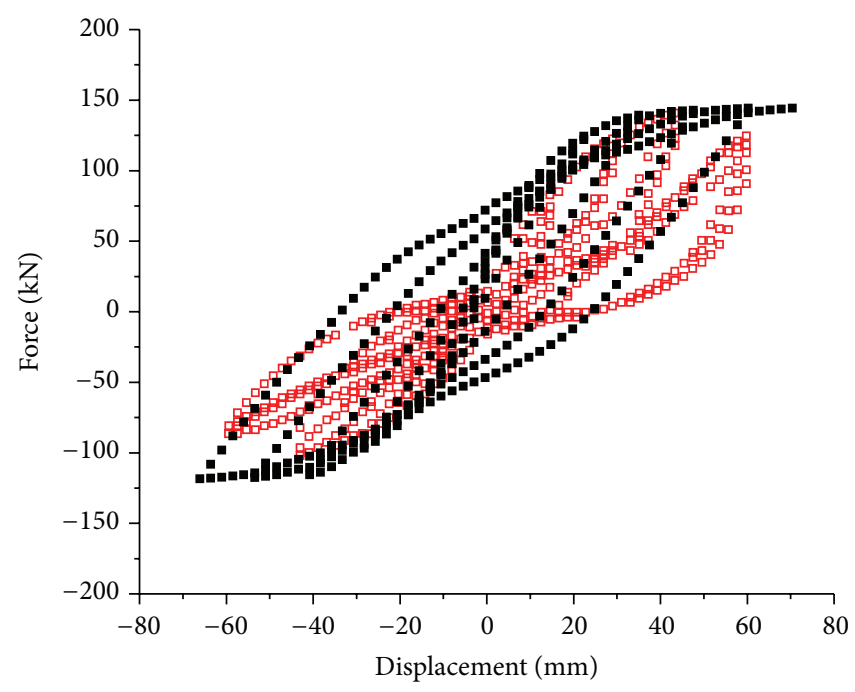

- Simulate KJ-1

口 Test KJ-1

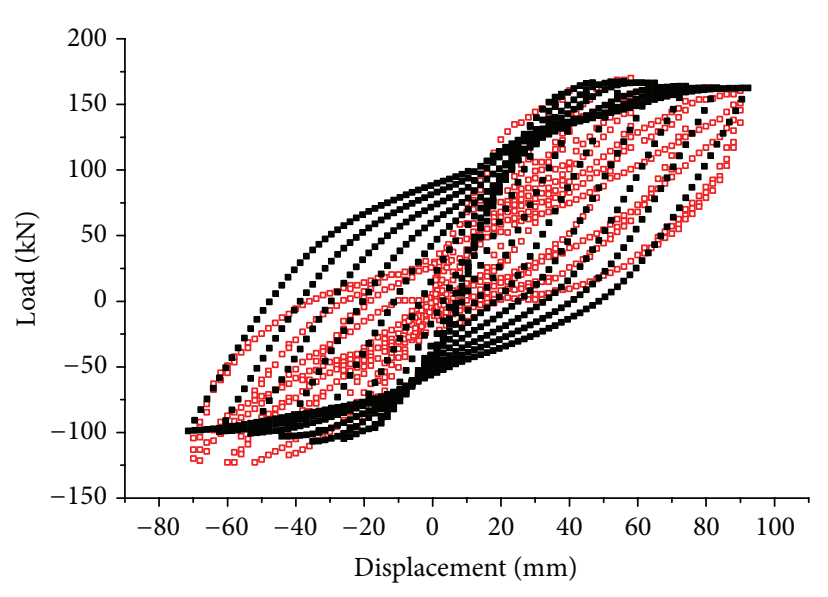

- Simulate KJ-2

口 Test KJ-2

(a) $\mathrm{KJ}-1$

(b) KJ-2

FIGURE 11: Hysteretic curve of KJ-1 and KJ-2.

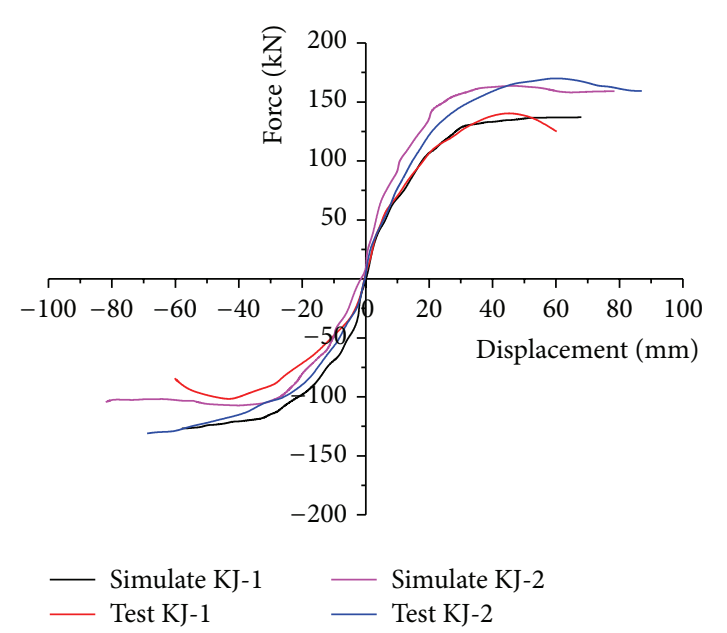

FIGURE 12: Skeleton curve of KJ-1 and KJ-2.

(2) Numerical results agree with the experimental ones on the whole. That is partially because the material objects adopted in the numerical model fit well with the experiment. It can be noticed that the numerical hysteretic circle is plumper than the experimental one, for the reason that the numerical model is an ideal one without considering the factors of bond-slip between concrete and reinforcement and cracks on concrete.

The skeleton curves of $\mathrm{KJ}-1$ and $\mathrm{KJ}-2$ are shown in Figure 12 . They are very close to each other at the initial loading stage. When it comes to the later loading stage, they present bigger difference, which proves that CFRP sheets enhance the capacity of KJ-2 noticeably.
5.2. Displacement Ductility. As previously mentioned, the yield force and displacement are obtained by first yield point method, and their accuracy is subjected to testers' subjective judgments [28-30]. Hence, Park procedure [35] is employed in this research to get yield force and displacement. The force and displacement at yield, peak, and ultimate point and ductility of KJ-1 and KJ-2 are illustrated in Table 1. The seismic performance is evaluated through displacement ductility. Compared with the reference specimen (KJ-1), the capacities of deformation, ductility, and load-bearing ability of CFRP sheets strengthened damaged specimen (KJ2 ) are remarkably improved. The ultimate displacements in push and pull directions of experimental and numerical results have increased up to 47 and $25 \%$ and 22.5 and 36\%, respectively. In addition, the maximum loads have increased up to 19.2 and $29.3 \%$ and 14.3 and $11 \%$, respectively.

5.3. Stiffness Degradation and Energy Dissipation. Figure 13 illustrates the stiffness degradation of KJ-1 and KJ-2 during loading procedure utilizing secant stiffness method. Stiffness degradation rate of $\mathrm{KJ}-1$ specimen is very close to $\mathrm{KJ}-2$ at the initial stage; when it comes to the later stage, the stiffness degradation rate of KJ-1 decreases faster compared to KJ-2. The result indicates that CFRP sheets can remarkably confine cracked concrete and improve the lateral stiffness of RC frame at elastic-plastic stage and plastic stage.

The structural energy dissipation is evaluated by the equivalent viscous damping factor. As illustrated in Figure 14, the equivalent viscous damping factor $h_{e}$ [36] is calculated based on the areas of hysteretic loop and corresponding triangle; that is, $h_{e}=(1 / 2 \pi)\left(S_{A B C} / S_{O B D}\right)$. The relation curve of equivalent viscous damping factor and corresponding displacement is depicted in Figure 15. As can be seen in Figure 15, (a) the equivalent viscous damping factor grows 
TABLE 1: Load, displacement, and ductility factor of KJ-1 and KJ-2.

\begin{tabular}{|c|c|c|c|c|c|c|c|c|c|}
\hline \multirow{2}{*}{\multicolumn{2}{|c|}{ Specimen number }} & \multirow[b]{2}{*}{ Loading direction } & \multicolumn{2}{|c|}{ Yield point } & \multicolumn{2}{|c|}{ Peak point } & \multicolumn{2}{|c|}{ Ultimate point } & \multirow[b]{2}{*}{ Ductility factor } \\
\hline & & & $\begin{array}{c}\text { Load } \\
\text { kN }\end{array}$ & $\begin{array}{l}\text { Displacement } \\
\mathrm{mm}\end{array}$ & $\begin{array}{l}\text { Load } \\
\mathrm{kN}\end{array}$ & $\begin{array}{l}\text { Displacement } \\
\mathrm{mm}\end{array}$ & $\begin{array}{c}\text { Load } \\
\mathrm{kN}\end{array}$ & $\begin{array}{l}\text { Displacement } \\
\mathrm{mm}\end{array}$ & \\
\hline \multirow{4}{*}{ Test } & \multirow{2}{*}{$\mathrm{KJ}-1$} & Push & 94.24 & 19.69 & 142.4 & 44.7 & 120.7 & 61.2 & 3.1 \\
\hline & & Pull & 66.04 & 19.05 & 103.8 & 44.2 & 88.0 & 57.2 & 3.0 \\
\hline & \multirow{2}{*}{$\mathrm{KJ}-2$} & Push & 118.79 & 22.34 & 169.8 & 58.4 & 144 & 89.9 & 4.0 \\
\hline & & Pull & 95.82 & 23.92 & 134.2 & 65.9 & 124.6 & 71.4 & 3.0 \\
\hline \multirow{4}{*}{ Simulation } & \multirow{2}{*}{$\mathrm{KJ}-1$} & Push & 106.5 & 19.98 & 143.1 & 45.5 & 140.3 & 64.1 & 3.2 \\
\hline & & Pull & 94.8 & 18.72 & 94.0 & 36.8 & 93.9 & 54.5 & 2.9 \\
\hline & \multirow{2}{*}{$\mathrm{KJ}-2$} & Push & 141.67 & 21.44 & 163.59 & 51.7 & 157.4 & 78.5 & 3.7 \\
\hline & & Pull & 94.01 & 24.0 & 104.1 & 54.24 & 102.77 & 73.9 & 3.1 \\
\hline
\end{tabular}

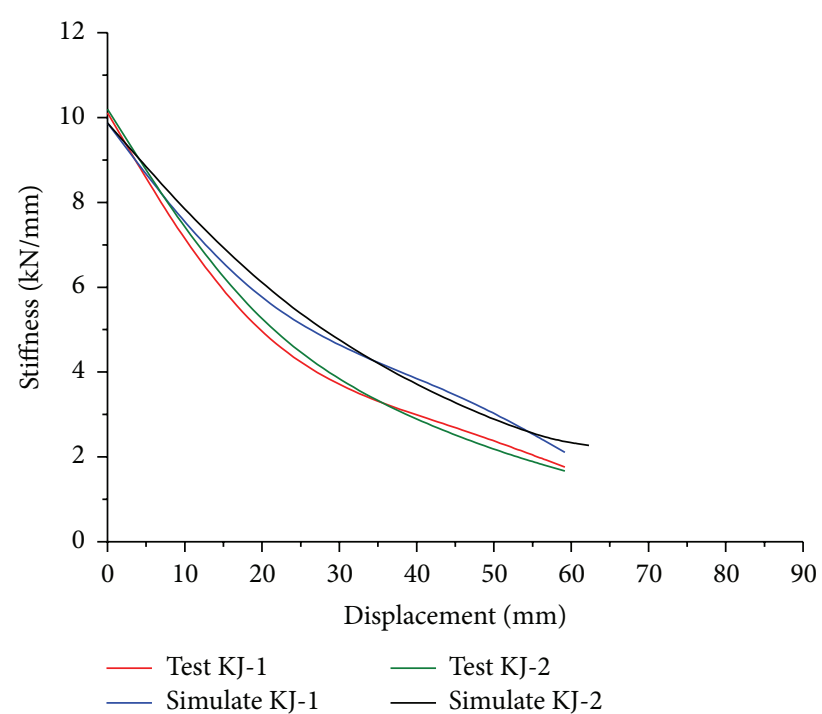

FIgURE 13: Stiffness degradation of KJ-1 and KJ-2.

with the increase of displacement, but the ratio of increase has little change; (b) the increase of equivalent viscous damping factor verifies that energy dissipation of specimens grows gradually; and (c) the equivalent viscous damping factor of $\mathrm{KJ}-2$ is higher than that of $\mathrm{KJ}-1$, which indicates that specimen of $\mathrm{KJ}-2$ is superior in energy dissipation to $\mathrm{KJ}-1$.

\section{Conclusions}

A low reversed cyclic test on seismic performance of reference specimen (KJ-1) and CFRP strengthened damaged RC frame (KJ-2) is conducted and the experimental result is compared with the numerical one. The following conclusions can be drawn:

(1) The CFRR sheets can remarkably improve bearing capacity of damaged RC frame including yield and maximum load. At elastic stage, the elastic stiffness of specimen KJ-1 and elastic stiffness of specimen KJ-2 are fairly close to each other. At elastic-plastic

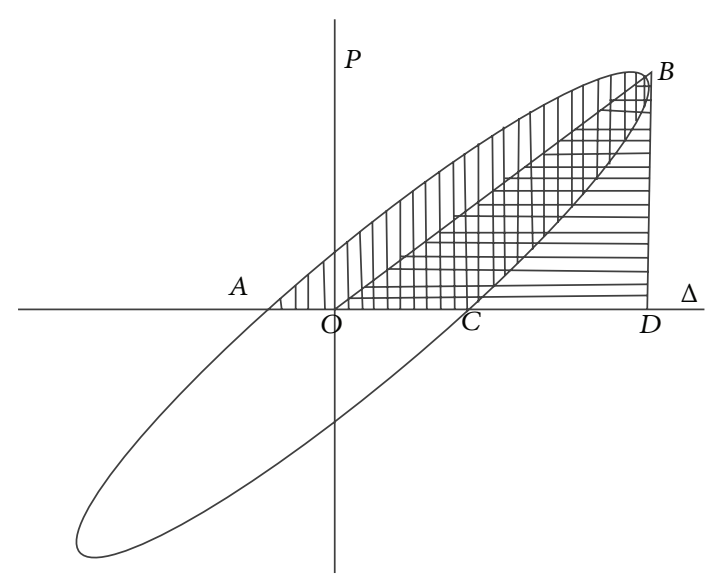

FIGURE 14: Sketch of equivalent viscous damping factor.

stage, the stiffness of specimen KJ-2 is improved dramatically compared with KJ-1.

(2) The ultimate displacement and ductility of KJ-2 precede those of KJ-1, which indicates that CFRP sheets can noticeably enhance ductility of RC frame and improve seismic performance eventually.

(3) Even though the cracks are not treated in this test, the CFRP sheets strengthened scheme significantly improves the seismic performance of RC frame. Therefore, this method is practical and effective in retrofitting damaged $\mathrm{RC}$ frame.

(4) The ideal fiber element model is used in numerical simulation ignoring the factors such as cracks in the frame and bond-slip between reinforcement and concrete, which leads to some deviation between numerical and experimental results.

\section{Competing Interests}

The authors declare that there are no competing interests regarding the publication of this paper. 


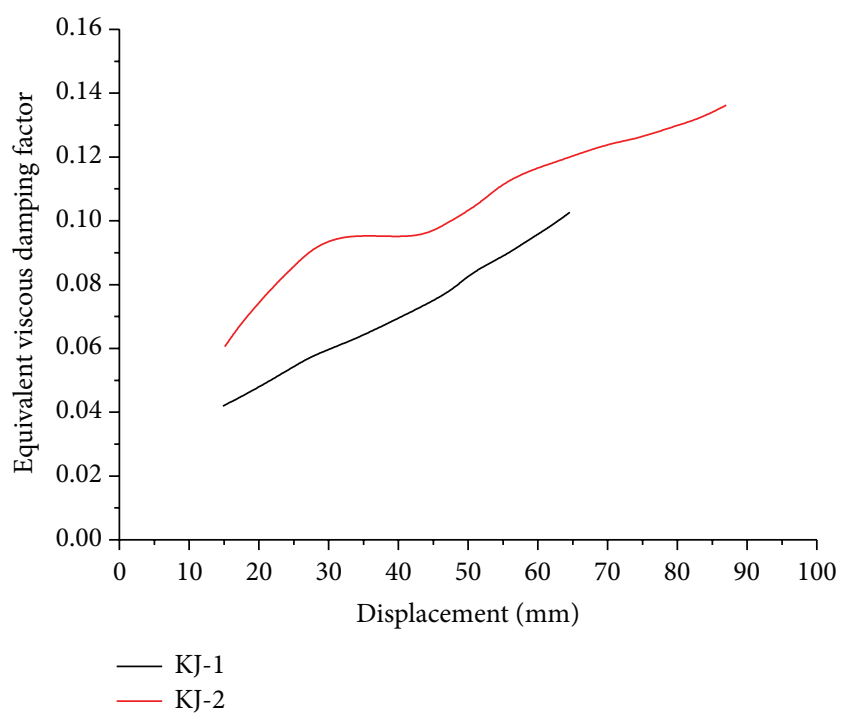

FIGURE 15: Energy dissipation of KJ-1 and KJ-2.

\section{Acknowledgments}

This study was financially supported by National Natural Foundation of china in 2012 (no. 51178259) and Postgraduate Innovation Fund of Shandong University of Science and Technology (no. YC150328).

\section{References}

[1] Y. Lieping, L. Xinzheng, Z. Shiyang, and L. Yi, "Seismic collapse resistance of RC frame structrual -case studies on seismic damages of several RC frames under exterme ground motion in Wenchuan earthquake," Journal of Building Structures, vol. 30, pp. 67-76, 2009.

[2] Y. LiePing, L. Yi, and P. Peng, "Seismic damange of building structrue of XuanKou Middle school in YingXiu town," Buildings Structure, vol. 39, pp. 54-57, 2009.

[3] L. Van Den Einde, L. Zhao, and F. Seible, "Use of FRP composites in civil structural applications," Construction and Building Materials, vol. 17, no. 6-7, pp. 389-403, 2003.

[4] L. C. Hollaway, "A review of the present and future utilisation of FRP composites in the civil infrastructure with reference to their important in-service properties," Construction and Building Materials, vol. 24, no. 12, pp. 2419-2445, 2010.

[5] Z. Ke, Y. Qingrui, Y. Lieping, and Z. Shuhong, "Experimental research on ductility improvement of concrete colum strenghtend FPs," Industrial Construction, pp. 16-19, 2000.

[6] W. Gang, L. Zhitao, and J. Jianbiao, "Experimental research ons seismic performance of reinforced concrete column strengthened CFRP sheets," Building Structure, vol. 32, pp. 42-45, 2002.

[7] W. Gang, A. Lin, and L. Zhitao, "Experimental study on bending properties of reinforced concrete beams strengthened with carbon fiber sheets," Building Structure, vol. 30, pp. 3-10, 2000.

[8] L. Jinjun and W. Tianwen, "Experimental study on the beamcolumn joint strengthened with CFRP under low-cycle reversed load," Building Structure, vol. 40, pp. 70-73, 2010.

[9] L. Zhoudao, H. Tao, and X. Liping, "An initail study on performance of damaged interior beam-cloumn-slab subassemblies strengthened by carbon fiber reinforced plastic(CFRP)," Industrial Construction, vol. 33, pp. 9-12, 2003.

[10] W. Xinling, Z. Juntao, L. lin, and Y. Zhangtang, "Experimental study on seismic behavrior of perfect RC frame strenthened by CFRP sheets," Journal of ZhengZhou University (Engineering Science), vol. 29, pp. 81-85, 2008.

[11] X. Li, L. Liu, H.-L. Lv, and S.-Y. Sha, "Seismic retrofit of short RC coupling beams using CFRP composites," Magazine of Concrete Research, vol. 68, no. 5, pp. 260-270, 2016.

[12] A. Khalifa and A. Nanni, "Rehabilitation of rectangular simply supported RC beams with shear deficiencies using CFRP composites," Construction and Building Materials, vol. 16, no. 3, pp. 135-146, 2002.

[13] H. M. Tanarslan, "Repairing and strengthening of earthquakedamaged RC beams with CFRP strips," Magazine of Concrete Research, vol. 62, no. 5, pp. 365-378, 2010.

[14] F. Colomb, H. Tobbi, E. Ferrier, and P. Hamelin, "Seismic retrofit of reinforced concrete short columns by CFRP materials," Composite Structures, vol. 82, no. 4, pp. 475-487, 2008.

[15] S. A. Sheikh and G. Yau, "Seismic behavior of concrete columns confined with steel and fiber-reinforced polymers," ACI Structural Journal, vol. 99, no. 1, pp. 72-80, 2002.

[16] P. Yin, L. Huang, L. Yan, and D. Zhu, "Compressive behavior of concrete confined by CFRP and transverse spiral reinforcement. Part A: experimental study," Materials and Structures, vol. 49, no. 3, pp. 1001-1011, 2016.

[17] O. Ozcan, B. Binici, and G. Ozcebe, "Improving seismic performance of deficient reinforced concrete columns using carbon fiber-reinforced polymers," Engineering Structures, vol. 30, no. 6, pp. 1632-1646, 2008.

[18] S. H. Alsayed, Y. A. Al-Salloum, T. H. Almusallam, and N. A. Siddiqui, "Seismic response of FRP-upgraded exterior RC Beam-column joints," Journal of Composites for Construction, vol. 14, no. 2, pp. 195-208, 2010.

[19] A. M. Elsouri and M. H. Harajli, "Repair and FRP strengthening of earthquake-damaged RC shallow beam-column joints," Advances in Structural Engineering, vol. 18, no. 2, pp. 237-249, 2015.

[20] R. Garcia, Y. Jemaa, Y. Helal, M. Guadagnini, and K. Pilakoutas, "Seismic strengthening of severely damaged beam-column RC joints using CFRP," Journal of Composites for Construction, vol. 18, no. 2, p. 10, 2014.

[21] A. Vatani-Oskouei, "Repairing of seismically damaged RC exterior beam-column connection using CFRP," Journal of Reinforced Plastics and Composites, vol.29, no. 21, pp.3257-3274, 2010.

[22] Ö. Yurdakul and Ö. Avşar, "Structural repairing of damaged reinforced concrete beam-column assemblies with CFRPs," Structural Engineering and Mechanics, vol. 54, no. 3, pp. 521-543, 2015.

[23] X. Wang, G. Zhao, L. Lin, J. Zhu, and Z. Yao, "Experimental study on seismic performance of serious damaged RC frame strengthened by CFRP sheets," Building Structure, vol. 40, pp. 50-53, 2010.

[24] R. Guo, X. Y. Liu, K. Liu, and W. Y. Bai, "A comparative experiment study of seismic performance of reinforced damaged RC frame," Journal of Hebei University of Technology, vol. 41, pp. 99102, 2012.

[25] National Standards of the People's Republic of China, "Code for seismic design of buildings," Tech. Rep. GB50011-2010, China Architecture \& Building Press, Beijing, China, 2010. 
[26] GB50010-2010, Code for Design of Concrete Structures, China Architecture \& Building Press, Beijing, China, 2010.

[27] "Specification of testing methods for earthquake resistant building," Tech. Rep. JGJ101-96, China Architecture \& Building Press, Beijing, China, 1997.

[28] F.-W. Qiu, "Developments of seismic testing methods for structures," China Civil Engineering Journal, no. 10, pp. 19-27, 2004.

[29] W. Dun, Z. Haiqiong, and L. Xinlin, "Loading protocols for quasi-static of structural components for buildings," Sichuan Building Science, pp. 54-59, 2014.

[30] F.-W. Qiu and P. Pan, "Quasi-static loading and control for structural test," China Civil Engineering Journal, vol. 35, no. 1, pp. 1-5, 2002.

[31] L. Ying-bin, L. Bo-quan, and S. Qing-xuan, "Performance levels and estimation indices of structures," World Earthquake Engineering, vol. 19, pp. 132-137, 2003.

[32] C. Jian, Z. Jing, and F. Xiaodan, "Repairable level under moderate earthquake action and seismic design method for RC frame buildings," Earthquake Engineering \& Structural Dynamics, vol. 26, pp. 13-19, 2006.

[33] B. D. Scott, R. Park, and M. J. N. Priestley, "Stress-strain behavior of concrete confined by overlapping hoops at low and high strain rates," Journal of the American Concrete Institute, vol. 79, no. 1, pp. 13-27, 1982.

[34] M. H. Harajli, "Axial stress-strain relationship for FRP confined circular and rectangular concrete columns," Cement and Concrete Composites, vol. 28, no. 10, pp. 938-948, 2006.

[35] R. Park, "Evaluation of ductility of structures and structural assemblages from laboratory testing," Bulletin of the New Zealand National Society for Earthquake Engineering, vol. 22, no. 3, pp. 155-166, 1989.

[36] Z. Bolong, Seismic Test of Structure, Seismological Press, 1989. 

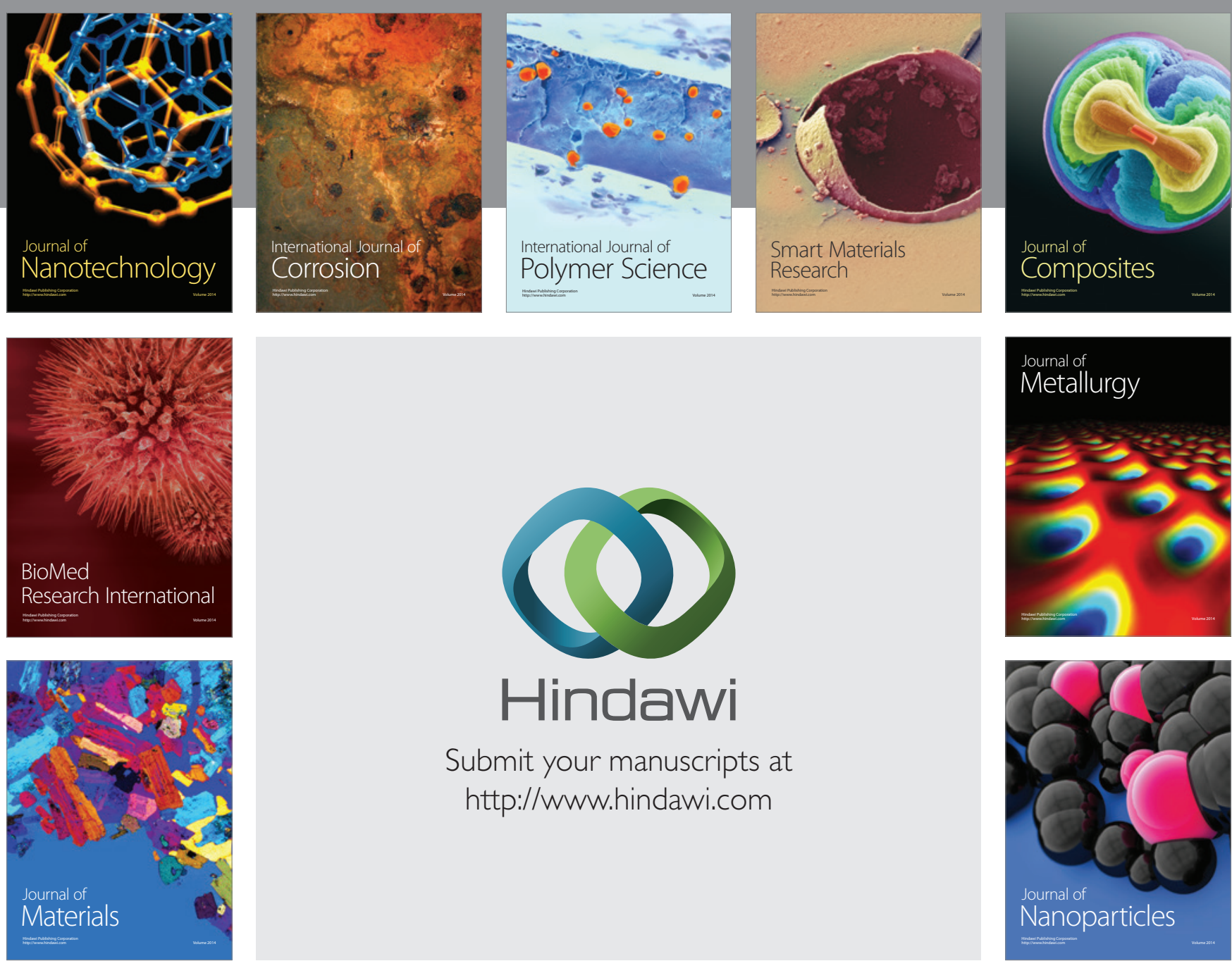

\section{Hindawi}

Submit your manuscripts at

http://www.hindawi.com

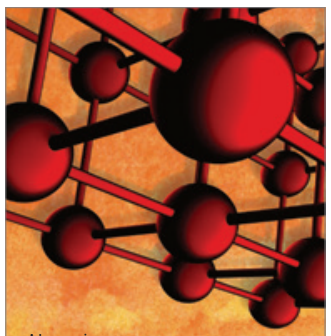

Materials Science and Engineering
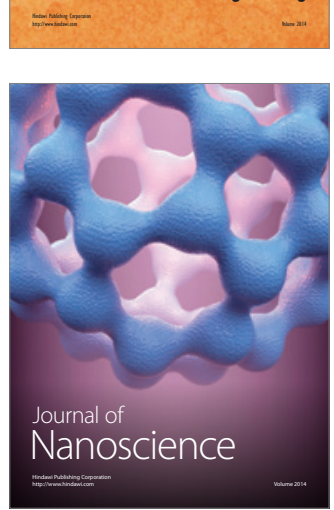
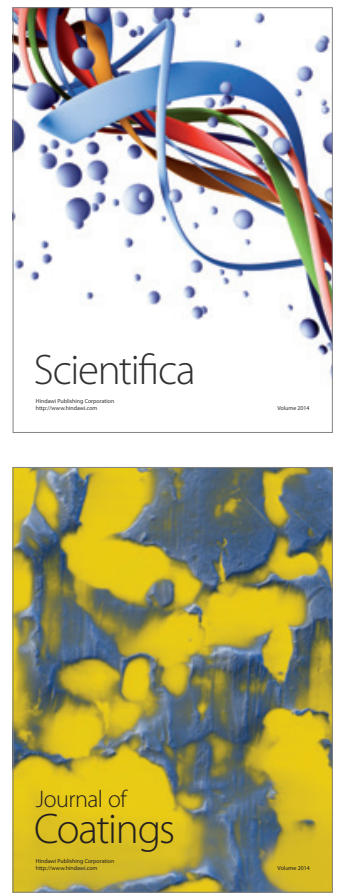
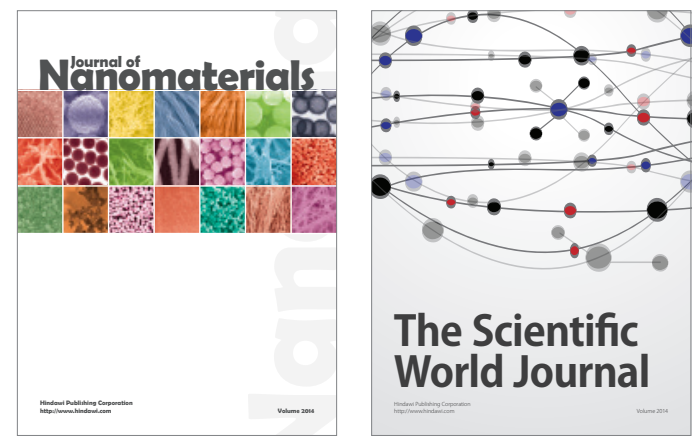

The Scientific World Journal
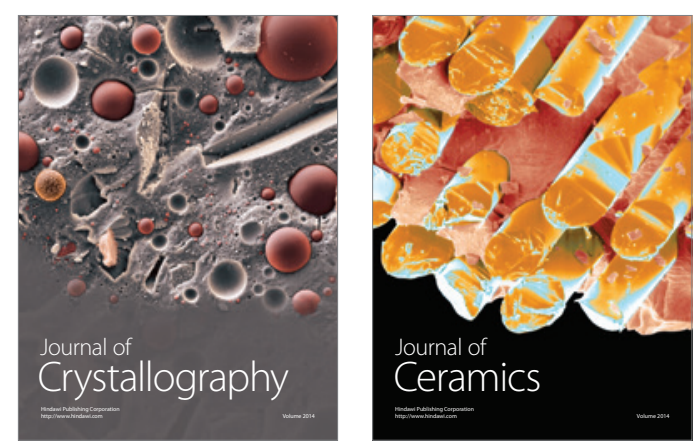
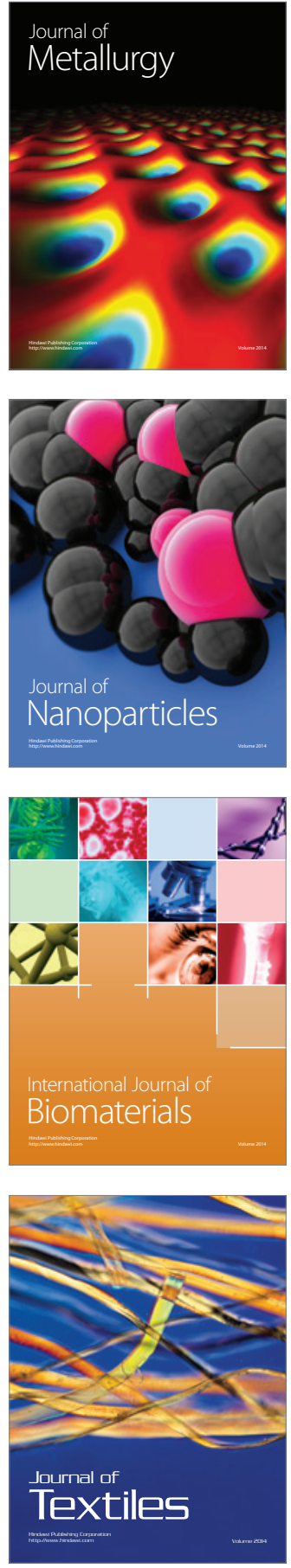